\title{
How to Ensure Food Supply to the Population of the Medieval Village of Loulé (1384-1488)
}

\author{
Luísa Fernanda Guerreiro Martins \\ Interdisciplinary History, Cultures and Societies Centre of the University of Évora (UID/HIS/00057/2013; \\ POCI-01-0145-FEDER-007702), Largo do Marquês de Marialva, n. ${ }^{\circ}$, Apartado 94, Évora 7000-809, Portugal
}

\begin{abstract}
Located in the centre of the Algarve, in the South of Portugal, the ancient village of Loulé has its origins in a Muslim medieval medina (8th Century). After the Christian Conquest of the South and namely of the Loulé territory in 1249, the Christian Administration, based on the city councils meetings, composed of good men, will have to reconcile the social and religious dynamics of the populations who stayed in the territory, formed by Jews, Muslims and Christians. Besides this social, cultural and religious scenario, local administration will also assure the management of production, distribution and sale of food needed to ensure the survival and the settlement of the populations in the territory. Part of that distribution included cereals, olive oil, wine, meat and fish, all of them representing the Mediterranean food basis of the populations from the South of the Iberian Peninsula. It is about this daily concern with food distribution and consumption, in a religious and culturally tripartite society that we intend to present this article, focusing the analysis on three types of food: cereals ("bread"), meat and fish. We intend to demonstrate how the medieval council of Loulé managed the production of the food and how the population was fed, using the Councillor Minutes of the Loulé City Council in the medieval Christian period. Since the documentation allows us to propose an interpretation for the consecrated trilogy of bread, olive oil and wine, we choose to underline three fundamental areas of the economy of the Algarve region: cattle raising and the supply of meat to the populations, the shortage of cereals with which the "bread" supply was ensured and the commercialization of fish. The provision of meat, cereals and fish ensured that the population was well fed, but the most interesting is that, the way the food distribution was made, allows us to understand the capacity to accept a tripartite society between "Christians”, "Moors” and "Jews".
\end{abstract}

Key words: Mediterranean food, medieval city, religious scenario, food production, distribution.

\section{Loulé: The Advantage of the Geographic Location $^{1}$}

The archaeological excavations done inside the historic area of Loulé have proved its Islamic origin, in spite of the finding of remains from Roman origin in neighbouring villages. It is thought that the village was grown around good sources of water and good farmland. These conditions have allowed human settlement, with the gradual development of urban areas inside the wall.

After the Christian Conquest of the South territory,

Corresponding author: ${ }^{1}$ Luísa Fernanda Guerreiro Martins, PhD; Member of Cidehus-University of Évora(UID/HIS/00057/2013;POCI-01-0145-FEDER-007702);

Collaborator of DIAITA-University of Coimbra; Senior Technician at the Loulé City Council; History of Food, Local History and History of Portuguese Presence in Africa. the Al-Gharb, the village of Loulé integrated the group of the most important settlements of the Algarve, privileged by the geographic centrality of the Municipality and the village itself, spreading from the mountains to the coast.

This geographic situation was also favourable to the circulation and the gathering of people and goods towards the urban centre, where the economical and social dynamics allowed the village to compete with cities, such as Faro and Tavira. It is therefore understandable that Loulé was the only urban area of the Algarve to receive a free fair charter, granted by the king Dinis on the 28th of July 1291.

After the Christian Conquest of the Southern Portuguese territory in 1249, by the king Afonso III, with crusaders campaign of the knights of the Order of 
Santiago, the administration and local governance stood in the hands of a few Christians, with the "Moors" and the "Jews" still living in the village, but in well-defined spaces, the "Moorish quarter" and the "Jewish quarter", respectively.

The co-existence of the three religious communities concentrated in the small area of the medieval village, with the possibility of extending to the wider Municipality, helped to understand the reasons behind concerns with food production, management and distribution. In addition, there are other interesting elements to the daily life of the medieval populations, mainly concerning precautions regarding tax avoidance, illegality and prevalent daily food typology of the people of Loulé in the 1300's.

\section{Meat}

In a territory where there was not yet a solid knight-based hierarchy, the social groups arranged to be represented at the council meetings which took place at the Council Chamber, the square or the main churchyard. There, the interests of the population could be defended in front of an organized administration, headed by the Mayor (representative of the central government with military power) and by the independent inspector (who surveyed the implementation of justice, councillor election and other officers, the supply and production of goods, rents and manpower) ${ }^{2}$. It would be like that in Loulé as in the rest of the Municipalities of the Algarve, where the craftsmen ensured the goods needed for domestic and foreign trade, while the rest of the populations sought to supply food to the village inhabitants, through farming and cattle raising.

In the context of this social, political and administrative framework, we note that one of the main concerns of the men responsible for the management of the Municipalities in the 14th and the

\footnotetext{
2 Maria Helena Cruz Coelho; Joaquim Romero Magalhães, 2008, O Poder Concelhio: das origens às cortes constituintes, Notas de História Social, Coimbra, CEFA-Centro de Estudos e Formação Autárquica, 2a edição revista, pp. 23-34.
}

15th centuries, was likely the daily food supply to the populations, so that they would not suffer from hunger. This reality was transversal to the European populations, from the North to the South, integrating here the fear of famine revealed in the years of 1384-1385 in the Portuguese territory.

The Councillor Minutes of the Loulé City Council, the most ancient in Portugal (1384), reveal to us the instructions from the Master of Avis, who became the king D. João I after the dynastic crisis of 1383-1385, sent to all the villages and the cities in order that the populations ensured the maintenance of the military fortifications, as well as the stock of essential goods to prevent their shortage in case of a Spanish invasion and siege. The documents reveal to us that it was ordered to the inhabitants of the village of Loule that they stack inside the wall all the "chamiça" (type of wood) needed to make the existents ovens within the wall to work: “[...] Outrossi outorgaram que todos os que teei os fornos rendados dentro da vila que o traga cada hum duzentos carregos de chamiça [...]”3 as well as cereals, wine and other goods: "Item outrosiacordarom que todos os que teeipam e vinhos e mantimentos nos arravaldes e nos termos que os tragam logo a cerca da vila [...]" ${ }^{\text {, }}$, in addition to the salt, essential to feed and goods preservation: “[...] que faça logo viir todo sal que sta nas sainhas ${ }^{5}$ acerca da dicta vila per guisa que se inmigos veerem que o nom achem hi. [...]"6.

But if this framework presents itself in a risk-of-a-war period, how would the daily life be in the medieval village of Loulé in times of peace?

\footnotetext{
${ }^{3}$ Councillor Minute of the Loulé City Council, 14th and 15th centuries, Separata da Revista Al-‘Ulyã, No. 7, Loulé, Loulé City Council, 1999/2000, Council Meeting of 09.01.1385-06.02.1385, p. 27.

${ }^{4}$ Council Meeting Minute of the 09.01.1385-06.02.1385, p. 28.

${ }^{5}$ Small tanks which kept the salt, brought from the coast, from Ludo region.

${ }^{6}$ Councillor Minutes of the Loulé City Council, 14th and 15th centuries, Separata da Revista Al-'Ulyã, No. 7, Loulé, Loulé City Council, 1999/2000, Council Meeting of 09.01.1385, p. 28.
} 
The interpretation of these Councillor Minutes clearly showed the existence of a strong social and political dynamic in the medieval village. Minutes resulted from councillor meetings, where the main subjects of discussion was, recurrently, the goods supply to the populations.

In fact, the information is inexistent regarding eventual prescriptions or complete descriptions about the families' food. Some will be disappointed if they are expecting a description about how or what people would eat in a meal. This analysed documentation only enables us to assemble what had to be ensured, as production, not only for supply and sale inside the village walls, but also for outside commerce. And from there, in an attempt for a description by approximation, one can reach an image of how meat, "bread" and fish were supplied, in a medieval village of the Algarve, considering the co-existence of the three religions: Judaism, Christianity and Islamism.

In contrast to the prevailing idea in the historiography that meat was not part of the daily food of the medieval populations of the Algarve, we note that its supply and distribution was a permanent concern. Archaeozoology has also revealed that meat consumption might have been significant. The collection of vocabulary and the registration of the documents excerpts analysed, demonstrate the existence of an economy that valued cattle farming to sell meat. The assumption that people would only eat meat from animals no longer suitable for work does not apply in this case. Here it was found a higher consumption of meat from younger animals, possibly reserved to the elite ${ }^{7}$.

In the Council of Loulé, where social groups dedicated to arts and crafts were outstanding, there had to be other groups exclusively dedicated to agriculture and cattle farming, in order to supply the ones that, in the village, bought these products. Cattle

7 C. M. Woolgar, 2009, "Banquetes y ayunos. La comida y el sentido desgusto en la Europa medieval”. Gastronomia. Historia del Paladar. Ed. Paul Freedman. València: Publicacions de la Universitat de València, p. 165. raisers and butchers were obliged to supply meat to the village, from Easter Sunday of that year to the Shrove Tuesday of the year after, as in the case of the butchers Airas Fernandes and Vasco Rouco:

"Como os carneceiros am a servir. [...] Airas Fernandes e Vasco Rouco carneceiros e preitarom com eles como ouvesem de talhar a carne per esta guisa a vaca a três soldos e o carneiro a quatro soldos e a cabra e cabrom a II soldos IIII dinheiros e a ovelha pello foro da vaca [...] E os dictos carneceiros diserom que eles talhariom desde dia de Pascoa ata Entrudo [...] emquanto hum for a comprar o outro talhe e sirva o concelho [...]."

Animals were cut and prepared in the butchery and put in exposition on the bench of the same butcher. By the population's requirement, its sale (prices, quality and exhibition for sale) was subjected to a strong surveillance and regulation.

Families would have the possibility to raise their animals in their backyard or in a small space of the garden, especially poultry, sheep, goats or pigs. But those would serve to domestic consumption and, hopefully, one or two animals could be sold, together with the poultry and the eggs. However the Council had the obligation to ensure a wide variety of cattle raising - ovine, caprine and bovine. And among the list, pork was in the background, probably not object of an overall demand, although it is farming in the family circle and in small numbers is documented ${ }^{9}$. Swines are also mentioned on complaints after their owners left them running free in the villages or in the fields, ruining crops and seeding, and the small paths where good water ran or when non-Christian buyers complained about the butcher mixing up all the meats,

\footnotetext{
${ }^{8}$ Councillor Minutes of the Loulé City Council, 14th and 15th centuries, Separata da Revista Al-‘Ulyã, No. 7, Loulé, Loulé City Council, 1999/2000, Council Meeting of the 19.09.1395, p. 64.

9 Iria Gonçalves, 2010. “A alimentação”, História da Vida Privada em Portugal. A Idade Média, dir. José Mattoso e coord. Bernardo Vasconcelos e Sousa, Lisboa, Círculo de Leitores, pp. 230-1.
} 
among them the pork meat ${ }^{10}$.

Besides being careful with the separation and the knowledge of the meat presented for sale at the butcher's, the butcher was also obliged to a fair and equal customer service. A demand like this was very peculiar when the priority customer service, with the best quality items, was reserved to the honoured citizens, the most powerful and with political and legislative power ${ }^{11}$. The "less honoured" inhabitants of Loulé would demand in the Municipal Council that the butchers stop giving first priority to the "sons" and the "youths" of the most powerful men that arrived to be immediately served. Below, an episode shows us that the powerful men still had the priority over the "small folk", except when the customer was an element of the Clergy. Then, that one would have priority over all the others:

“[...] Afomso Gonçallvez capellam de Santa Maria chegar ao açougue pidir carne ou pescado lhe dem logo posto que hiestem os bacios dos cavalleiros visto como há de hir aviar sua capella e missa e nom herazomhiiseerdetheudo" ${ }^{12}$.

In other words, "potties" or knights baskets should be served, naturally priority but, before the urgency of the chaplain duties, he had to be attended immediately. The chaplain had priority, the knights still had exclusivity and only after those the rest of the population could be served. Complaints seem to have no result.

In spite of these social questions, the documents reveal a generally peaceful interaction, where the representatives of the three religions came together-Christians, Muslims and Jews, nevertheless

${ }^{10}$ Councillor Minutes of the Loule City Council, 14th and 15th centuries, Separata da Revista Al-'Ulyã, No. 7, Loulé, Loulé City Council, 1999/2000, Council Meeting of the 17.11.1403, pp. 146-7.

${ }^{11}$ Iria Gonçalves, 2010. “A alimentação”, História da Vida Privada em Portugal. A Idade Média, dir. José Mattoso e coord. Bernardo Vasconcelos e Sousa, Lisboa, Círculo de Leitores, p. 236.

${ }^{12}$ Councillor Minutes of the Loule City Council, 14th and 15th centuries, Separata da Revista Al-'Ulyã, No. 7, Loulé, Loulé City Council, 1999/2000, Council Meeting of 1468, pp. 199-200. the latter living in specific places: the Moorish quarter and the Jewish quarter. Until the Edict of expulsion of the 5th December 1496, decreed by Manuel I, the three communities co-existed in the village and it seems that there was respect among them, in a cosmopolitan environment. It is true that, with the Christian domination and the emergence of the specific places for the Moorish and the Jewish to inhabit, some of the rights were abolished. It would have also happened in that way at some point with the butchers, in both the Jewish and the Moorish quarters, where each one, according to their religion, could be certain of the meat purity when buying it.

Under the Christian administration, a tax started to be required from the Moors and the Jews in order to have their own butchery. When that possibility was also taken from them, they had to accept the meats presented for sale in the butcheries managed by Christians. In those cases, the non-Christians managed that the local governance men compelled the Christian butchers to put the entire carcases for sale, so the consumers could easily recognize the meat, with no mistakes:

“[...] nenhum carneceiro nem merchom nem outra pessoa que talhe pees de vacas e bois e toiros mesturada com a carne que talhem nem cabeças das dictas reses nem lacoois nem hunhas de porcos e porcas [...]" ${ }^{, 13}$.

That is, that the whole animals were put on sale, with their heads and legs, without mixing the meat types. At least an identification of the piece bought was ensured.

In the documents analysed, the total references that appear in a count of the words related with animals and meats typologies reveal 65 references concerning the bovine, followed by 31 references to the ovine-caprine, 16 to swine, 11 to poultry and 2 to rabbits. These references are more indicative of the caution to avoid animals entering the farming fields, than that of the management of meat supply in the

${ }^{13}$ Council Meeting Minute of the 17.11.1403, pp. 146-7. 
village butcheries. However, the episode with the cattle raiser João Adaez demonstrates how the municipality managed meat distribution in the village. João Adaez, who was forced to sell 300 sheep to Diogo Afonso, butcher of the village, sold only 160, because meanwhile 30 animals had died and because Diogo Afonso himself had only bought those 160. So, Adaez asked permission to the municipality to sell the rest of the sheep to whomever he wanted, since he was losing money with the bad deal. The Council was divided when giving the final statement. If for some people he was compelled to sell the 300 sheep to the butcher of the municipality, and for not doing that he should pay a penalty, to others, the fact that he lost at first 30 animals from the 300 that he had raised, and then the butcher only bought him 160, leaving him with 110 animals on his own, gave the breeder the right to sell the remaining cattle. In the lack of agreement, the judge put the case to the vote of all good men in a Council meeting, in which the winner faction, with 15 votes, was the one that considered that João Adaez could sell the cattle wherever he wanted, against the faction that considered he should be fined, with 10 votes. And one of the councillors, Fernão d'Ovanha, stated that the missing animals could be compensated with the beef supply "que era a milhor carne pera a gente que o carneiro" 14 (translated: which was better meat for the people than sheep). Interesting observation in a curious episode, which might explain that the prevailing practice was sheep consumption, demonstrated an emerging intention from managers to compel people to get used to beef. Can we note here a political and religious intention?

\section{Fish}

Fish, another significant food in the Jewish, Christian and Islamic religions, emerges in the daily life of the medieval populations of the Algarve as a fundamental element to fill other shortages. In the specific cases of the Christians, it allowed them to

${ }^{14}$ Council Meeting Minute of the 14.04.1468, pp. 201-2. fulfil the fast or abstinence days required by the Church.

The fish traders "trumpeted" fish sale separately with and without scales, according to the normative issued by the City Council, being the fish with scales the most preferred by the consumers. This is consistent with the Jewish and Islamic religions that preferred the fish with scales in detriment of "leather fish”, considered impure (swordfish, moray, dogfish, and skate, among others).

The surveillance of the "almotacés" (Inspectors of Weights and Measures) to the fish traders required asking about the origin of the fish carried. And these should respond with the truth, under oath. This is because, after that, the prices should be set. If hake cost 5 or 6 reais in Faro, it could only cost between 12 and 15 reais in Loulé, under penalty of 100 pounds to the offender ${ }^{15}$. It was also the obligation of the "almotacés” to prevent these traders from selling fish in their own houses, a situation that meant tax avoidance, risk in the product quality and an inadequate implementation of prices in relation to that stipulated by the City Council for sale in the market. In the event of failure to comply, the fines to offenders were significant, in an amount of 200 pounds and the duty to start selling always at the village market ${ }^{16}$. The inspector "almotacé" would also be punished in case of benevolence towards illegality. In case of complaint by severe default of his obligations, he would also be charged with a fine. This explains the inspectors' zeal in fulfilling their duties.

Another irregular situation denounced by the councillors was that these fish traders sold "cabeças das peixotas" (fish heads) brought from Faro, when in this city they were thrown away. Also here the justice was relentless. Fish traders were forbidden to sell fish heads and if they have them they were forced to eat

\footnotetext{
${ }^{15}$ Council Meeting Minute of the 10.11.1403, "Councillor Minutes of Loulé City Council, 14th and 15th centuries”, Op. Cit., p. 146.

${ }^{16}$ Council Meeting Minute of the 22.12.1403, "Councillor Minutes of the Loulé City Council, 14th and 15th centuries", Op. Cit., p. 149.
} 
them or offer them.

In fact, all the attention given to the "regatões" and "regateiras" (fish traders) would not be enough. For one reason or the other it is understandable why the Loulé City Council decided to have a man paid by the Council, living and working in Faro, to ensure fish supply to Loulé during the whole year, with the proper quality and the strict fulfilment of the prices ${ }^{17}$. To ensure the quality of the fish, there was also the need to guarantee that it was sold by the morning, with a previous scheduling. That is, the exact days for selling fish should be on Wednesdays, Fridays and Saturdays, forcing the fishing to be done on Tuesdays to sell on Wednesdays, on Thursdays to sell on Fridays and on Fridays to sell on Saturdays ${ }^{18}$.

\section{Cereals}

The word "bread" means more than the food itself. "Bread" can be any type of cereal, as it can represent the daily food that satiates hunger. In the specific case of this research, "bread" corresponds to cereals in its generality and, most particularly, to wheat, with which hunger and diseases were prevented among the populations.

Afonso III, the king that conquered the Al-Gharb ${ }^{19}$ in 1249, in the Foral ${ }^{20}$ he granted to Loulé, kept for himself and his heirs the bread ovens, as well as the windmills of Quarteira, the "presses" and the watermills, avoiding that this structures were

${ }^{17}$ Council Meeting Minute of the 18.03.1408, "Councillor Minutes of the Loulé City Council, 14th and 15th centuries”, Op. Cit., p. 168.

${ }_{18}$ Council Meeting Minute of the 04.02.1408, "Councillor Minutes of the Loulé City Council, 14th and 15th centuries", Op. Cit., p. 162.

19 Algarve.

20 "Foral", a Charter with a law that rules the population of a Council, it also establishes the kind of relationship between managers of the local public administration and the king. Although tending to be centralizing, this document restricted arbitrariness of the great men and the good men. This Charter defined taxes and service provisions, territory taxation, private property rights, social hierarchic functionality. And by the Charter, the king also ensures his incomes relating to salt pans, windmills, water-mills, ovens, winepresses, cellar and law of Patronate. controlled by private individuals. If Northern Europe used windmills to transform cereals in flour, Southern Europe used watermills, close to watercourses. Water availability and the existence of one or two weirs ${ }^{21}$ would be enough for the development of a population settlement around it.

When the watermill did not belong to the king, it would be a nobleman, a count or a duke's property, that paid a wage to a miller or rented him the space. And the water from the stream, where the watermill was located, could only be used for irrigation when the mill was not working. The "Moor" Azemete Louzeiro had to ask the Council for permission, that is to the powerful men of the village, so that on Sundays, the day in which Christians do not work - the owners of the "watermills"22, he could use the water from the stream to irrigate his vegetable garden ${ }^{23}$.

Yet the miller, limited by the rent that he should pay to the king or the lordship and the wheat shortage in the Algarvian territory, had to divert some wheat flour or cereal whenever there was work. There are some descriptions of cases when the miller, secretively, added fine sand to the wheat flour, before providing it to the customer ${ }^{24}$. In the case of Loulé this severe illegality was not found but we registered a population complaint, claiming that, when the grains were delivered to the millers, these ones transformed the raw material and gave back a quantity of flour

\footnotetext{
${ }^{21}$ For centuries, water-mills or weirs have made part of the humanized rural landscape of Portuguese places, small villages and villages. Their functionality became ingrained in population's habits and customs, in popular festival traditions, in oral memory. Bear witness to that the painting of Amadeo de Souza Cardoso-“Canção d'açude, poema em cor” (1916; Calouste Gulbenkian Museum), exhibited in the Contemporaneous Art Museum in Lisbon by the occasion of the exhibition dedicated to the painter (January to February 2017), where the painter wrote: "Millers of this weir love the white virgin. Millers of this weir love the wheat flour".

${ }^{22}$ Watermills were also named of "weirs", "windmills" or "water wheels".

${ }^{23}$ Luísa Fernanda Guerreiro Martins, 2016. Contributos para a História da Alimentação Algarvia a partir das Atas de Vereação do Concelho de Loulé (1384-1488), Faro, Direção Regional de Cultura do Algarve, p. 50.

${ }^{24}$ Heinrich Eduard Jacob, 2003. 6000 Anos de Pão. Lisbon: Antígona, p. 210.
} 
which was inconsistent with the amount of cereals delivered. To deal with these situations, the good men council decided that everyone had to pay to the "grinder" three reais per bushel of flour delivered ${ }^{25}$.

Other strict measures to prevent hunger were the prohibitions of the cattle (bovine, poultry and other domestic animals) to get close to the seeded fields ${ }^{26}$. Or when there was wheat shortage, the farmers were forbidden to feed bran to their pigs, because they were destined for human consumption ${ }^{27}$.

In addition to the process of transformation of wheat into wheat flour, there was also the need to monitor, in the urban space, the selling place of the bread, its prices, who sold it and who handled it. If millers were subjected to suspicion from the suppliers of cereals for processing, bakers, who sold the bread in the Council bakeries, were carefully chosen. Also here, the religious factor is imposed when referring to the purity of the white or "perfect" bread and to who handled it. In the case of Loulé, we find a widow, Maria Annes, who was once a rich and honoured woman and was now living in poverty, who received a public instrument, a license, to become a "franchised baker" for two reasons: The first one, "por o dictologar ser mais onrado e as gentes stranheiras e homens onrados a verem boopam branco stremado e bem fecto de moo" ${ }^{28}$. The second one, because the Council was granting a place of honour and power to a person who was also known as honoured. Not having to pay taxes, she was, nevertheless, forced to knead and to bake white and well-done bread, at the risk of

\footnotetext{
${ }^{25}$ Councillor Minutes of the Loulé City Council, 14th and 15th centuries, Separata da Revista Al-'Ulyã, No. 7, Loulé, Loulé City Council, 1999/2000, Council Meeting of the 23.06.1403, p. 133.

${ }^{26}$ These precautions were widespread to the fields planted with fig trees, vineyards or other fruit trees.

${ }^{27}$ Luísa Fernanda Guerreiro Martins, 2016. Contributos para a História da Alimentação Algarvia a partir das Atas de Vereação do Concelho de Loulé (1384-1488), Faro, Direção Regional de Cultura do Algarve, p. 51.

${ }^{28}$ Councillor Minutes of the Loule City Council, 14th and 15th centuries, Separata da Revista Al-'Ulyã, No. 7, Loulé, Loulé City Council, 1999/2000, Council Meeting of the 05.05.1408, pp. 192-3.
}

incurring in fines as the others bakers of the village, in case she did not fulfil her obligations.

The much-reduced production and the consumption of cereals were regulated by municipal postures. And when there was cereal shortage, they had to be imported from other country regions, mainly from the lands of Entre-Douro-e-Minho, Beiras, Estremadura and Alentejo or from Castela or Andaluzia. The year of 1385 was marked by a severe cereal crisis, with the record of instances when bread sale reached speculative prices. In order to try to resolve such shortage, the public notary Diego Rodriguez went to Beja and "Canpo d'Ourique comprar saca de pan per a dicta vila”"29 (asked for a bag of bread for the village). In its turn, the good men council initiated cereal price fixing and decreed that all cereal, namely wheat should be sold inside the Council and its sale was forbidden outside its territory ${ }^{30}$.

Another radical measure decided by the good men council was that all the fields of Almargem de Bilhas, where excellent farm lands predominated between the mountains and the coastal region of the council, stopped farming grazing to cattle run and started to plant wheat. The same was decided to the field horta d'el Rei, close to the village wall. This decision clashed with the interests of the powerful class, who did not want to renounce to their fields to plant feed to their animals. Yet, it seems that the majority of the good men council have managed to take forward their intention as, in 1423, the Bilhas field was already producing the amount of 2 moios, 40 bushels of wheat and 1 moio of barley ${ }^{31}$.

In addition to the difficulty in supplying wheat to the population due to its shortage, the municipality was also obliged to supply to the highest instances of

\footnotetext{
${ }^{29}$ Council Meeting of the 09.01.1385-06.02.1385, p. 27.

${ }^{30}$ Luísa Fernanda Guerreiro Martins, 2016. Contributos para a História da Alimentação Algarvia a partir das Atas de Vereação do Concelho de Loulé (1384-1488), Faro, Direção Regional de Cultura do Algarve, p. 48.

31 PT/AMLLE/CMLLE/E/A/01/Lv007, 1423-1425, Livro de Receita e Despesa do Procurador do Concelho de Loulé (46 fólios), fls.12,12v. Our transcription.
} 
the Church in the Algarve, the bishop and master of Silves, 40 moios of wheat kept in the village barn $^{32}$.

\section{Conclusion}

We observed that Loulé, due to its geographic location has the advantage of being a focal point of people, goods and cultures and thanks to that and to its natural resources, early since, it became a medieval village of reference nationwide.

The councillor minutes allow us to discern the good men council's concern towards production, management and distribution of the goods needed to feed the populations, in order that its people did not suffer from hunger. To this end, they paid attention to the requests of the "Christians", "Moorish" and "Jewish" representatives. It seems that the position of local governance men would be to meet the requests presented by their people. However, they faced several royal decisions, legislative and fiscal standards which had been put into practice by its employees, for an accurate council management.

In fact it would be a major concern to all the municipalities of the Algarve, to ensure cereal supply, and of wheat in particular, as well as meat, fish and all fruit and vegetables distribution, which became part of the territory daily diet and the domestic and foreign trade (vegetables, figs, grapes, olives, among others).

Cereal farming, management and distribution in the early Middle Age of Loulé reveal a scenario of permanent shortage, particularly of wheat, which was demanded the most. Other feed matters of concern to village men and governance men were meat and fish (supply, types, prices, quality and cultural and religious preferences).

These local managers concerning also included prosecuting economic offenses, which were frequently practiced by officers and craftsmen in the process of commercial trade. Therefore, the inspectors surveillance in relation to the functioning of the

32 Councillor Minutes of the Loulé City Council, 15th century, Separata da Revista Al-'Ulyã, No. 10, Loulé, Loulé City Council, 2004, Council Meeting of the 02.07.1493, p. 118. winepresses, butcheries, mills and watermills-where wheat and other cereals were transformed into flour-and also, of the bakeries, where bread was made and sold. That supervision included, for example, the inspection of areas to verify cleaning, olive oil and winepresses tank's size, and the well functioning of the watermills, besides the surveillance over the raw material transformation processes, the quantities that entered and the ones transformed. Prices, weights and measures should also be controlled.

The intermediaries, especially the butchers, the millers and the bakers were people constantly on the aims of inspectors and other council administrators, due to their reputation of frequently trying to deceive customers. Other famous intermediaries were fish traders who tried to monopolize fish or vegetables sale $^{33}$ to increase prices to their own liking, often selling in the their own houses instead of in the market, in default of local administration. Everything was supervised aiming to combat fraud and ensure food supply with quality and fairness.

Another element which deserves to be highlighted in this research is the importance of the religion not only over the goods available to people, but the areas where they are sold, and also who sells and handles them. In the Algarvian territory, in the 14th and 15th centuries one can realize the selling places, whether the council butchery, whether the watermills and the bakeries would not be rented to Jews or to Moors. Places where food sacred as bread, olive oil, wine and meat was sold, would not be places where the central and local administration approved the "aforamento" (the right to the use and fruition of immovable

\footnotetext{
33 The "hortelãos", the "regateiras" and the "vendedeiras" (types of traders) of the village of Loulé wanted to make a free sale of vegetables by the price of one real or half real. So, the general judge and the councillors have decided by a council order that the price of vegetables would be of 5 soldos and if anybody was caught selling by a different price, would pay a fine of 50 libras. Councillor Minutes of the Loulé City Council, 14th and 15th centuries, Separata da Revista Al-'Ulyã, No. 7, Loulé, Loulé City Council, 1999/2000, Council Meeting of the 20.10.1403, p. 144.
} 
property) to non-Christians. Jews were increasingly restricted to arts and crafts: blacksmiths, shoemakers, tailors, gunsmiths, pharmacists, weavers, etc. and more and more kept away from the jobs that entailed food handling. Maybe for that reason it is understandable why the Jews and the Moors claimed the differentiation and identification of the meat sold in the council Butchery, or that the Moor gardener Azemete Louzeiro asked permission for watering his vegetable garden on Sundays, when the watermill, certainly exploited by a Christian, was not working, or that the council managers concerned about the purity and the honesty of the baker. Agriculture, fishing and many arts and crafts were permitted to the Moors.

To conclude a brief comment, it seems that the medieval village of Loulé would have a thriving economic, social and demographic dynamics, which would only decrease during the second half of the 16th century, a period when all the attention was focused on efforts for maritime expansion, often, to the detriment, of the well-being of the kingdom's villages and cities.

\section{Primary Manuscript, Transcript and Published}

[1] "Councillor Minutes of the Loulé City Council, 14th and 15th Centuries.” separata da Revista Al-‘Ulyã, No. 7, Loulé City Council, 1999/2000.

[2] "Councillor Minutes of the Loulé City Council, 15th Century.” supplement of Revista Al- 'Ulyã, No. 10, Loulé City Council, 2004.

[3] Livro de Receitas e Despesas do Concelho (1450-1451), transcript and published by Fátima Botão, (2009), A construção de uma identidade urbana no Algarve medieval. Casal de Cambra: Caleidoscópio.

[4] Livro de Receita e Despesa do Procurador do Concelho de Loulé (46 fólios), fls.12,12v. (our transcription); PT/AMLLE/CMLLE/E/A/01/Lv007, 1423-5.

[5] Martins, L. F. G. 1992. "Memórias Paroquiais do Concelho de Loulé.” Revista Al-‘Ulyã, No. 10, Loulé: Câmara Municipal de Loulé, pp. 387-435.

\section{References}

[1] Aguilera, C. 2001. História da Alimentação Mediterrânica. Lisboa: Terramar.
[2] Almeida, M. D. V. 1998. "O azeite na alimentação mediterrânica.” $1^{\circ}$ Seminário Sobre Alimentação e Saúde, Faro: Escola Superior Tecnologia, Campus da Penha. p. 11.

[3] Barros, M. F. L. 2009. "Os últimos mouros de Loulé: percurso de uma minoria.” Revista Al'-Ulyã, No. 13, Loulé: Câmara Municipal de Loulé, p. 121.

[4] Batista, P. 2006 "Alimentação no concelho de Loulé no século XIV.” Revista Al'-Ulyã, No. 11, Loulé: Câmara Municipal de Loulé, pp. 69-81.

[5] Bernardes, J. P., and Oliveira, L. F. 2006. A Vinha e o Vinho no Algarve, o renascer de uma velha tradição. Faro: Comissão de Coordenação e Desenvolvimento Regional do Algarve.

[6] Botão, M. F. 2009. A construção de uma identidade urbana no Algarve medieval. Casal de Cambra: Caleidoscópio.

[7] Carrusca, S. 2001. Loulé, o património artístico. Loulé: Câmara Municipal de Loulé.

[8] Coelho, M. H. C. 1983. "Apontamentos sobre a comida e a bebida do campesinato coimbrão em tempos medievos.” In Revista de História Económica e Social, dir. de Vitorino Magalhães Godinho, No. 12, Lisboa: Livraria Sá da Costa, pp. 91-101.

[9] Coelho, M. H. C., and Magalhães, J. R. 2008. O Poder Concelhio: das origens às cortes constituintes, Notas de História Social, Coimbra, CEFA-Centro de Estudos e Formação Autárquica, 2nd ed. revista.

[10] Coelho, M. H. C. 2013. “As cidades medievais portuguesas: população.” Actas das Conferências do I Congresso Histórico Internacional-As Cidades na História: População, Guimarães: Câmara Municipal, pp. 143-62.

[11] Coelho, M. H. C. 2013. “A festa-a convivialidade.” In História da Vida Privada em Portugal. A Idade Média, dir. de José Mattoso e coord. de Bernardo Vasconcelos e Sousa, $1^{\text {a }}$ edição em 2010, $2^{\mathrm{a}}$ edição em 2013. Lisboa: Círculo de Leitores.

[12] Dias, J. J. A. 1987. "Estratificação económico-demográfica do concelho de Loulé nos finais da Idade Média.” Actas das I Jornadas de História Medieval do Algarve e Andaluzia, Loulé: Câmara Municipal de Loulé, pp. 205-29.

[13] Dias, J. J. A. 1989. "Agravos do Algarve às Cortes de Lisboa de 1498.” In Actas das III Jornadas de História Medieval do Algarve e Andaluzia, Loulé: Câmara Municipal de Loulé, pp. 171-95.

[14] Dolader, M. A. M. 1996. "L'alimentation juive médiévale." In Histoire de l'Alimentation, Dir. de Jean-Louis Flandrin e Massimo Montanari. Paris: Fayard, pp. 367-87.

[15] Dolader, M. A. 2008. “A Alimentação Judaica Medieval.” 
História da Alimentação, 1. Dos primórdios à Idade Média, Coord. Jean-Louis Flandrin e MassimoMontanari. Lisboa: Terramar.

[16] Duarte, L. M. 1987. "Eleições municipais no Algarve no início do século XV.” In Actas das I Jornadas de História Medieval do Algarve e Andaluzia, Loulé: Câmara Municipal de Loulé, pp. 297-347.

[17] Duarte, L. M., and Coelho, M. H. C. 1996. “A fiscalidade em exercício: o pedido dos 60 milhões no Almoxarifado de Loulé.” In Revista da Faculdade de Letras da Universidade do Porto, $2^{\mathrm{a}}$ série, vol. XIII, Porto: Faculdade de Letras da Universidade do Porto, pp. 205-29.

[18] Duarte, L. M. 2004. "Portugal visto de Loulé, 1492-1497." Actas de Vereação de Loulé, Século XV. Suplemento da Revista Al'-Ulyã, No. 10. Loulé: Câmara Municipal de Loulé.

[19] Ferreira, M. V. 2003. “A fruta de Loulé na Europa medieval - análise de manuscritos do século XV.” Revista Al'-Ulyã, No. 9, Loulé: Câmara Municipal de Loulé, pp. 215-39.

[20] Flandrin, J.-L., and Montanari, M. 2008. História da Alimentação, Vol. I. Lisboa: Terramar.

[21] Flandrin, J.-L., and Montanari, M. 1996. Histoire de l'Alimentation. Paris: Fayard.

[22] Fontes, J. L. I. 2006. “A Expansão Medieval.” In A Vinha e o Vinho no Algarve, o renascer de uma velha tradição, coord. de João Pedro Bernardes e Luís Filipe Oliveira, Faro: Comissão de Coordenação e Desenvolvimento Regional do Algarve, p. 25.

[23] Gonçalves, I. n.d. "À mesa, com o rei de Portugal (séculos XII-XIII).” In Revista da Faculdade de Letras, Lisboa: Faculdade de Ciências Sociais e Humanas da Universidade Nova, pp. 15-32.

[24] Gonçalves, I. 1987. "Despesas da Câmara Municipal de Loulé em meados do século XV.” In Actas das I Jornadas de História Medieval do Algarve e Andaluzia, Loulé: Câmara Municipal de Loulé, pp. 185-97.

[25] Gonçalves, I. 2010. “A alimentação.” In História da Vida Privada em Portugal. A Idade Média, dir. de José Mattoso e coord. de Bernardo Vasconcelos e Sousa, Lisboa: Círculo de Leitores.

[26] Gouveia, J. M. B. 2002. “A oliveira e o azeite na História.” In O Azeite em Portugal. Lisboa: Edições Inapa.

[27] Jacob, H. E. 2003. 6000 Anos de Pão, Lisboa: Antígona.

[28] Langhans, F.-P. 1949. Apontamentos para a História do Azeite em Portugal. Separata do Boletim da Junta Nacional do Azeite. Lisboa.

[29] Lopes, P. 2005. “A Modernidade Alimentar.” In volução Simbólica do Acto Alimentar. Lisboa: Edições Colibri.

[30] Magalhães, J. A. R. 1970. Para o estudo do Algarve económico durante o século XVI. Lisboa: Edição
Cosmos.

[31] Magalhães, J. A. R. 2004. "Livro do Registo do Tabelamento dos Ofícios e Serviços, 1555-1562.” Revista Al'-Ulyã, No. 10, Loulé: Câmara Municipal de Loulé, pp. 273-352.

[32] Marques, A. H. O. 1968. Introdução à História da Agricultura em Portugal. A questão cerealífera durante a Idade Média, 2nd ed. Lisboa: Edições Cosmos.

[33] Marques, A. H. O. 1987. “A Mesa.” In A Sociedade Medieval Portuguesa. Aspectos da Vida Quotidiana, Cap. I, 5th ed. Lisboa: Sá da Costa.

[34] Marques, A. H. O. 1987. "Para a história do Algarve Medieval.” In Actas das I Jornadas de História Medieval do Algarve e Andaluzia, Loulé: Câmara Municipal de Loulé, pp. 55-60.

[35] Marques, A. H. O. 1989. "Para a história do concelho de Loulé na Idade Média.” In Actas das III Jornadas de História Medieval do Algarve e Andaluzia, Loulé: Câmara Municipal de Loulé, pp. 17-33.

[36] Martins, I. M. P. 1989. O Foral de Loulé de 1266, 2nd ed. Loulé: Câmara Municipal de Loulé.

[37] Martins, L. F. G. 2009. "O azeite no quotidiano do concelho de Loulé.” In Cadernos do Arquivo. Loulé: Câmara Municipal de Loulé.

[38] Martins, L. F. G. 2016. Contributos para a História da Alimentação Algarvia a partir das Atas de Vereação do Concelho de Loulé (1384-1488). Faro: Direção Regional de Cultura do Algarve.

[39] Miller, H. D. 2009. "Los pláceres delconsumo: El nacimiento de la cocinaislámica medieval.” In Gastronomia. Historia del Paladar, edited by Paul Freedman. València: Publicacions de la Universitat de València.

[40] Moreno, H. B. 1989. "A Nobreza do Algarve nos fins da Idade Média.” In Actas das III Jornadas de História Medieval do Algarve e Andaluzia, Loulé: Câmara Municipal de Loulé, pp. 135-49.

[41] Rodrigues, T. F., and Reis, C. F. 1989. “A vida familiar no Algarve na primeira metade do século XVI: alguns aspectos do quotidiano.” In Actas das III Jornadas de História Medieval do Algarve e Andaluzia, Loulé: Câmara Municipal de Loulé, pp. 291-307.

[42] Rosenberger, B. 1996. "La cuisine arabe et son apport à la cuisine européenne.” In Histoire de l'Alimentation, Dir. de Jean-Louis Flandrin e Massimo Montanari. Paris: Fayard, pp. 345-65.

[43] Santos, M. J. A. 1997. "Vinho, pescados, fruta e outras viandas em tempos medievais.” In A Alimentação em Portugal na Idade Média, Coimbra, p. 68.

[44] Saramago, A. 2001. Cozinha Algarvia: enquadramento histórico e receitas. Lisboa: Assírio e Alvim.

[45] Saramago, A. 2007. "O legado árabe na História da Alimentação do Algarve.” In História da Alimentação, 
coord. Carlos Guardado da Silva. Encontros de História Turres Veteras IX, Lisbon: Edições Colibri \& Câmara Municipal de Torres Vedras \& Universidade de Lisboa, p. 19.

[46] Silva, C. G. D. 2007. História da Alimentação. Lisbon: Edições Colibri.

[47] Silva, M. S. 1989. "Para o estudo da produção frutícola do concelho de Loulé (Os «Livros da Repartição da Fruta» do século XV.” In Actas das III Jornadas de História Medieval do Algarve e Andaluzia. Loulé:
Câmara Municipal de Loulé, p. 255.

[48] Simões, J. M. 2012. História económica, social e urbana de Loulé, Col. Cadernos do Arquivo, No. 7. Loulé: Câmara Municipal de Loulé.

[49] Woolgar, C. M. 2009. "Banquetes y ayunos. La comida y el sentido desgustoen la Europa medieval.” In Gastronomia. Historia del Paladar, edited by Paul Freedman. València: Publicacions de la Universitat de València. 